\title{
PEMIKIRAN HARUN NASUTION TENTANG PENDIDIKAN DI PERGURUAN TINGGI AGAMA ISLAM
}

\author{
Oleh
}

Muslim

\begin{abstract}
ABSTRAK
The thought of Harun Nasution's educational reform began to be socialized and applied since he first entered the elite ranks of IAIN Jakarta (in 1969, after he completed his studies at Me Gill University Canada). At that time Harun had the impression that the thought at IAIN before he joined it was very narrow, allergic to things that smelled of renewal. An indication of this is that books containing renewed ideas, such as books written by Muhammad Abduh, for example, are prohibited from being taught at IAIN. Thought at IAIN, said Harun, is still traditional, which specializes in fiqh, not thinking. Whereas understanding of Islamic religion which is fiqh oriented, according to Harun, if all problems are returned to fiqh (Islamic law), then we will go back to 20 years ago. In addition, if the IAIN is still allowed to be controlled by the narrow fiqh thinking, the government will see that the IAIN gives birth to narrow and fundamentalist thinking in a negative sense, which is why sanat may be the IAIN will be closed. Similar criticism was also raised by several rectors of Islamic higher education institutions in this country. Azumardi Azra said that the decline in Islamic Studies was due to the weak ability of the principals in PTAI who did not have knowledge and perspectives in the basic Islamic sciences. In addition, Amin Abdullah also stated that in PTAI, the Philosophy of Philosophy is still weak and not much research and books have been formulated for this field. In this regard, the first step taken by Harun Nasution in order to renew his Islam at IAIN is to renew the curriculum (in the narrow sense of the study material) of IAIN. In connection with this matter, Aaron proposed that the introduction of Islamic Studies be included in the IAIN curriculum. This course is intended to provide insights into Islam that are as broad and basic as possible. Besides that Harun also proposed the inclusion of courses in philosophy, kalam science, Sufism, monotheism, sociology, and research methodology. With the updated curriculum, Harun believes that it will help open broad insights about Islam, an urgent matter in a society that is undergoing a process of modernization.
\end{abstract}

Keywords: Harun Nasution, Education, Higher Education

\section{PENDAHULUAN}

Pemikiran pembaharuan pendidikan Harun Nasution mulai disosialisasikan dan diaplikasikan sejak ia pertama masuk dijajaran elite IAIN Jakarta (tahun 1969, setelah ia menyelesaikan studinya di Universitas Me Gill Canada). Saat itu Harun mempunyai kesan bahwa pemikiran di IAIN sebelum ia bergabung ke dalamnya adalah sangat sempit, alergi terhadap hal-hal yang berbau pembaharuan. Indikasi dari hal tersebut adalah bawah buku-buku yang berisi pemikiran pembaharuan, seperti bukubuku karangan Muhammad Abduh, misalnya, dilarang diajarkan di IAIN. Pemikiran di IAIN , kata Harun, masih tradisional, dimana spesialisasinya ke fiqh, bukan pemikiran. Padahal pemahaman agama Islam yang fiqh oriented, menurut Harun, jika semua masalah dikembalikan kepada fiqh (hukum Islam), maka kita akan kembali ke 20 tahun yang silam. Di Samping itu, jika IAIN tetap dibiarkannya dikuasai oleh pemikiran fiqh yang sempit itu, maka pemerintah akan memandang bahwa IAIN melahirkan pemikiran sempit dan fundamentalis dalam arti negatif, yang karenanya sanat boleh jadi IAIN akan ditutup. ${ }^{1}$
Kritik senada juga dilontarkan oleh beberapa rector perguruan tinggi Agama Islam di negara ini. Azumardi Azra mengatakan bahwa kemerosotan dalam Islamic Studies karena lemahnya kemampuan para lpelaku di PTAI yag tidak memiliki pengetahuan dan perspektif dalam ilmu-ilmu dasar Islam. Selain itu Amin Abdullah juga menyatakan bahwa di PTAI masih lemah tradisi Filsafat dan belum banyaknya penelitian serta buku yang dirumuskan untuk bidang ini. $^{2}$

Berkenaan dengan hal tersebut, langkah pertama yang dilakukan Harun Nasution dalam rangka pembaharuan Islamnya di IAIN adalah memperbaharui kurikulum (dalam arti sempit materi kajian) IAIN. Dalam hubungannya dengan hal tersebut Harun mengusulkan agar dimasukkan mata kuliah Pengantar Ilmu Agama Islam ke dalam kurikulum IAIN. Mata kuliah ini dimaksudkan untuk memberi wawasan tentang Islam yang luas dan mendasar sendinimungkin. Disamping itu harun juga mengusulkan dimasukannya mata kuliah-ata kuliah filsafat, ilmu kalam, tasawuf, tauhid, sosiologi, dan metodologi riset. Dengan kurikulum yang diperbaharui itu Harun percaya akan membantu 
membuka wawasan yang luas tentang Islam, suatu hal yang mendesak dalam masyarakat yang sedang mengalami proses modernisasi. ${ }^{3}$

Lebih jauh lagi dalam membincarakan pembaharuan dibidang pendidikan Islam Harun memberikan perhatian terhadap empat hal yang menurutnya adalah komponen penting dalam suatu proses pendidikan, yaitu: tujuan, bahan, metode, dan kualitas guru. ${ }^{4}$

Mengenai tujuan pendidikan Islam Harun mengatakan ada hal-hal yang perlu diredefnisi. Tujuan pendidikan agama di Indonesia untuk membentuk manusia "bertakwa". Manusia bertakwa pada umumnya diartinkan sebagai manusia yang patuh kepada Tuhan dalam menjalankan ibadah. Tujuan ini, kata Harun, agaknya didasarkan pada pendekatan yang menguatkan ajaran pemujaan dan penyembahan Tuhan dari pada ajaran-ajaran lainnya. Padahal di samping ibadah, agama Islam masih mempunyai ajaran-ajaran lainnya, terutama ajaran mengenai nilai baik dan buruk, tegasnya ajaran moral. Hubungan agama Islam dengan moral sangatlah cepat, bahkan, dengan merujuk sebuah hadis yang mengemukakan tujuan diutusnya Rasul, Harun mengatakan bahwa moral adalah merupakan hal yang essensial dalam agama. Oleh karena itu, agar tujuan pendidikan Agama Islam tersebut lebih akurat, maka tern "taqwa" yang menjadi titik tekanya perlu diredefinisi, sehingga elaborasi tujuan pendidikan agama Islam akan lebih komprehensif. ${ }^{5}$

Mengacu kepada tujuan pendidikan agama Islam yang telah diredefinisi diatas, Harun mengatakan bahwa pendidikan agama islam haruslah didasarkan tujuan moral, spiritual, dan intelektual. Dalam hubungannya dengan hal tersebut, perlu ditegaskan bahwa Tuhan sebenarnya tidak digambarkansebagai sebuah sosok yang ditakuti, sebuah sosok yang pemarah dan suka memasukkan manusia kedalam siksa neraka atas kesalahan-kesalahan yang dilakukan oleh manusia. Ajaran agama yang memberikan gambaran mengenai Tuhan serupa ini, menurut Harun, akan dipatuhi karena perasaan takut kepada Allah, dan jika perasaan takut itu hilang maka ajaran itu akan ditinggalkan. ${ }^{6}$

Mengenai metode yang dapat diterapkan dalam proses pendidikan Islam, Harun Nasution menyebutkan beberapa metode, antara lain; pemberian contoh atau teladan, pemberian nasehat, problem solving, partisipasi, dan metode tanya jawab atau diskusi. Sedangkan mengenai kualitas pendidik, Harun Nasution menetapkan beberapa syarat bagi para pendidikan agama Islam, yaitu; 1) sanggup memberi contoh teladan, 2)menguasai ilmu-ilmu yang erat kaitannya dengan pendidikan, seperti; peadagogi, psikologi dan yang sejenisnya, 3) mempunyai pengetahuan yang luas tentang agama, dan 4) mempunyai pengetahuan yang minimal sebanding dengan pengetahuan yang dipelajari oleh peserta didik.

\section{Tujuan Penelitian}

Berdasarkan permasalahan penelitian ini, tujuan umum dan penelitian ini adalah untuk mengetahui pemikiran, Harun Nasution tetang Pendidikan Islam di Indonesia dan Pengaruhnya. Sedangkan mengenai manfaat dan signifikasi dan penelitian yang penulis lakukan ini adalah:

1. Secara praktis manfaat dan penelitian ini adalah meningkatkan pernahaman penulis terhadap pemikiran Harun nasution tentang pendidikan Islam di Indonesi dan Pengaruhnya.

2. Secara teoritis manfaat dan penelitina yang penulis ajukan ini adalah:

3. Untuk memperkaya khazanah keilmuan khususnya dilingkungan Sekolah Tinggi Agama Islam Negeri (STAIN) Jurai Siwo Metro Lampung, maupun lingkungan akademik IAIN dan masyarakat pada umumnya.

4. Sebagai kontribusi pemikiran dalam pembinaan pendidikan Islam yang ada di Indonesia dengan latar belakang budaya yang komplek dan majemuk.

\section{TINJAUAN PUSTAKA}

Harun Nasution lahir pada hari Selasa tepatnya pada tanggal 23 September 1919 di Pematang Siantar, Sumatera Utara, Putra dari Abdul Jabber Ahmad, seorang pedagang asal Mandailing dan qadhi (penghulu) pada masa pemerintahan Belanda di Kabupaten Simalungn. Sedangkan ibunya Maimunah seorang boru di Mandailing Tapanuli.

Pendidikan Harun dimulai di HIS selama tujuh tahun sehingga berusia 14 tahun, ia belajar bahasa Belanda dan ilmu pengetahuan umum di sekolah, dan di sekolah pulalah ia dididik disiplin dengan ketat. Harun sangat menyenangi pelajaran ilmu pengetahuan alam dan sejarah. Kemudian Harun melanjutkan sekolahnya di MIK (modern islamietischekweekscool) di Bukit Tinggi yaitu sekolah guru menengah pertama swasta modern, selama tiga tahun ia belajar di sana dengan bahasa pengantar yaitu bahasa Belanda.

Di sekolah inilah mulai terlihat daya kritisnya terhadap hukum-hukum Islam yang bertolak belakang dengan apa yang dianut oleh kedua orangtua dan masyarakat sekitarnya. Kemudian pada tahun 1938

\footnotetext{
7 Abdul Halim, Teologi Islam Rasional, (Liputat Pers,Jakarta. 2001), h 3

${ }^{8}$ Harun Nasution, Refleksi Pembaharuan Pemikiran Islam, (LSAF, Jakarta), h. 5
} 
Harun hijrah ke Mesir melanjutkan pendidikannya di Al Azhar. ${ }^{9}$ Selanjutnya ia menjadi kandidat di universitas yang sama pada tahun 1942. Dan ia menyelesaikan studi sosial dengan Gelar Sarjana Muda dan Universitas Amerika di Cairo pada tahun 1952. Kemudian pada tahun 1953 ia kembali ke Indonesia dan bertugas di Departemen Luar Negeri bagian Timur Tengah.

Pada akhir Desember 1955 ia kembali melanjutkan kerjanya di Kedutaan Republik Indonesia di Brussels. Karena pengaruh komunis di Indonesia begitu kuat, Harun yang anti komunis memutuskan keluar dari kedutaan dan ke Mesir untuk melanjutkan studinya. Pada tahun 1965 ia memperoleh gelar Magister. Dan pada tahun 1969 ia kembali ke tanah air dan melibatkan diri di dunia akademisi dan menjadi dosen di IAIN Jakarta.

\section{A. Background Sosio-kultur Harun Nasution}

Harun Nasution berasal dari keluarga yang terhitung elite pada waktu itu. Ibunya adalah seorang ulama Mandailing yang pemah bermukim di Mekkah.

Sementara itu, ayahnyapun mampu menunaikan ibadah haji ketika masih kecil, di mana sekembalinya dari Mekkah ayahnya menjadi pedagang yang sukses, bahkan mengimpor barang dagangannya dan Singapura.

\section{0}

Selain ayah Harun Nasution banyak mempelajari Islam dari para ulama di daerahnya, ia (ayahnya) juga banyak membaca kitab kuning berbahasa Melayu. Oleh karenanya, ayah Harun mempunyai ilmu tentang Islam khususnya fiqh yang cukup untuk ukuran zamannya. Berkat pengetahuannya itu, sang ayah dapat diangkat oleh pemerintah kolonial menjadi Kepala Agama dan merangkap menjadi Hakim Agama serta Imam Masjid di Kabupaten Simalungun. Dari jabatannya sebagai Kepala Agama ini sang ayah memperoleh masukan uang yang menurut pengakuan Harun, cukup besar, hingga mampu memperluas tanah miliknya untuk pertanian (perkebunan) karet, salak, kayu manis, kelapa, dan yang lainnya.

Dengan latar belakang sosial, ekonomi, dan budaya seperti itu, Harun Nasution kecil, disamping belajar agama di rumah, ia juga dapat masuk sekolah Belanda (HIS). Setelah 7 tahun di HIS, Harun ingin melanjutkan sekolahnya ke MULO, akan tetapi orang tuanya menghendaki agar Harun sekolah agama. Sehingga ia kemudian masuk sekolah agama setingkat MULO yang beraliran modern, Moderne Islamiet sche Kweekschool (MIK) pada tahun 1934 di Bukit Tinggi. Sekolah ini adalah milik Abdul Ghaffar Jambek, putera Syekh Jamil Jambek. Di MIK ini ia menjadi tertarik dengan pelajaran ke-Islaman, sebab di sini ia memperoleh pandangan-pandangan yang maju tentang Islam. Sewaktu di Bukit Tinggi inilah Ia berkenalan dengan pemikiran-pemikiran Hamka, Zainal Abidin, dan Jamil Jambek. ${ }^{12}$

Sayangnya, walaupun sekolah ini bersemangat modern, namun karena sekolah ini miskin, maka Harun mempunyai hasrat untuk melanjutkan sekolah ke Solo, karena sana ada sekolah Muhammadiyah, sekolah yang dianggap cocok dengan fikirannya. Akan tetapi, keinginannya itu tidak kesampaian karena tidak mendapat izin dari orang tuanya. Alasan orang tua Harun tidak mengizinkan keinginan Harun tersebut adalah karena perkembangan pandangan keagamaan Harun yang ditempa lewat sekolah-sekolah dan lingkungan kaum muda di Bukit Tinggi yang bersemangat modern itu dipandang oleh mereka (orang tua Harun) menyimpang. Perlu dicatat, konflik antara kaum muda dengan kaum tua waktu itu sangat kuat. Oleh karena itu, untuk kembali meluruskan keIslaman Harun, orang tua Harun mengirim Harun ke Mekkah. Harun-pun tidak dapat menolak keinginan orang tuanya itu, akan tetapi ia mengajukan syarat agar setelah Ia belajar di Mekkah Ia diijinkan untuk melanjutkan studi ke Mesir. Keinginan untuk belajar di Mesir itu terinspirasi oleh cerita salah seorang alumni Mesir, Muhtar Yahya, yang mengatakan bahwa orang muda seperti Harun memang sebaiknya belajar di Mesir. Syarat dari Harun itu disetujui oleh orang tuanya, dan kemudian dengan kemampuan ekonomi yang kuat dan keinginan dan keluarganya tersebut, ia pergi ke Mekkah.

Di Mekkah, Harun hanya bertahan selama satu setengah tahun. Ia kemudian berkirim surat kepada orang tuanya dengan nada ultimatum, yaitu jika Ia tidak diperbolehkan untuk segera melanjutkan belajarnya ke Mesir, Ia tidak akan pulang ke Indonesia, Ia akan menjadi sopir di Mekkah. Ultimatum Harun ini efektif, sehingga kemudian orang tua Harun mengirim uang kepadanya untuk menuntut ilmu di Mesir.

Di Mesir Ia mula-mula mendalami Islam di Fakultas Ushuluddin Universitas AI-Azhar. Akan tetapi ia merasa tidak puas dan kemudian Ia pindah ke Universitas Amerika (Kairo). Di Universitas ini Harun tidak mendalami Islam, akan tetapi ia juga mendalami ilmu pendidikan dan ilmu-ilmu sosial. Selama beberapa tahun ia sempat bekerja di perusahaan swasta dan kemudian setamat dari Universitas Amerika, dengan berbekal ijazah "BA", Ia bekerja di Konsulat Indonesia di Kairo. Dari Konsulat itulah Harun, yang kemudian mempersunting seorang putri dari negeri Mesir, memulai karier diplomatiknya. Dari Mesir ia ditarik ke Jakarta, dan kemudian diposkan

\footnotetext{
${ }^{9} \mathrm{http}: / / \mathrm{www}$.google.com/pemikiranharunnasution

${ }^{10}$ Syaiful Mazuni, Reaktualisasi Teologi Muktazilah Bagi Pembaharuan Umat Islam.(Jakarta, Lembaga Studi Agama dan Filsafat, 1993),h.2

Ibid,hal.2
} 
sebagai sekretaris pada Kedutaan Besar Indonesia di Brussel.

Situasi politik dalam negeri Indonesia pada tahun 1960-an membuatnya mengundurkan diri dari karier diplomatik dan pulang ke Mesir. Di Mesir ia kembali menggeluti dunia ilmu di sebuah sekolah tinggi studi Islam, di bawah bimbingan salah seorang ulama fiqh Mesir, Abu Zahrah. Ketika belajar di sinilah Harun mendapat tawaran untuk mengambil studi Islam di Universitas Mc Gill, Kanada. Untuk tingkat Magister di Universitas ini, ia menulis tentang "Pemikiran Negara Islam Di Indonesia", sementara untuk disertasi Ph.D-nya Ia menulis "Posisi Akal Dalam Pemikiran Teologi Muhammad Abduh". Setelah meraih doktor, Harun kembali ke tanah air, dan mencurahkan perhatiannya pada pengembangan pemikiran Islam lewat IAIN. Ia sempat menjadi rektor IAIN Jakarta selama dua periode (1974-1982). Kemudian ia memelopori pendirian Pasca Sarjana untuk studi Islam di IAIN, dan hingga wafatnya (bulan Oktober 1998), ia bekerja sebagai Dekan Fakultas Pasca Sarjana IAIN Jakarta.

Seperti para pembaharu pada umumnya, Harun Nasution tergugah oleh kondisi umat Islam di sekelilingnya, di mana kondisi tersebut menurut pengamalan Harun adalah kondisi yang menampakkan kemunduran dari kondisi awal umat Islam, terutama di bidang pengembangan intelektual. ${ }^{16}$ Kondisi seperti itulah yang kemudian menurutnya menyebabkan perlunya upaya pembaharuan.

Pembaharuan menurut Harun sama maknanya dengan modernisasi, yaitu fikiran, aliran, gerakan dan usaha untuk merubah faham-faham, adat istiadat, institusiinstitusi lama dan sebagainya agar semua itu dapat disesuaikan dengan pendapat-pendapat dan keadaankeadaan baru yang ditimbulkan oleh pengembangan ilmu pengetahuan modern. ${ }^{17}$ Pembaharuan dalam Islam menurutnya mempunyai tujuan yang sama. Akan tetapi ia mengingatkan bahwa dalam Islam ada ajaran-ajaran yang bersifat mutlak, yang tidak dapat dirubah, dan ada ajaran-ajaran yang tidak bersifat tidak mutlak, yang dapat dirubah. Pembaharuan dapat dilakukan pada wilayah penafsiran atau interpretasi dalam aspek-aspek teologi, hukum, politik dan seterusnya, dan mengenai lembaga-lembaga.

Seperti apa yang penulis utarakan bahwa apa yang menyebabkan perlunya dilakukan pembaharuan dalam Islam adalah kesadaran mengenai kemunduran Islam, terutama dalam pengembangan intelektual di kalangan umat Islam, yang ini sangat disadari oleh Harun Nasution. Dari hasil kajian kesejarahan mengenai

${ }^{15}$ Syaiful Muzani, Islam Rasional (Bandung: Mizan.1995),hal.5

16 Harun Nasution. Islam Ditinjau dari berbagai Aspeknya(Jakarta; Bulan Bintang, 1975) hal.93

${ }_{17}^{17}$ Ibid,hal.94

${ }^{18}$ Harun Nasution, Pembaharuan dalam Islam (Jakarta; Bulan Bintang,1977)hal.207 pemikiran dan gerakan pembaharuan dl Mesir, Turki dan India, Harun Nasution sampai pada kesimpulan bahwa penyebab kemunduran Islam antara lain adalah penyimpangan dalam penghayatan dan pengamalan ajaran Islam. Harun mengatakan bahwa Islam yang dianut dan diamalkan umat Islam saat ini bukan lagi Islam yang sebenarnya. Ke dalam Islam telah masuk ajaran dan praktek yang berasal dari luar. Lebih jauh lagi, menurut Harun telah banyak masuk ke dalam Islam berbagai praktek yang tidak menguntungkan, dimana hal tersebut terutama dimulai sejak abad pertengahan IsIam.

Selain itu, menurut Harun, umat Islam mengalami kemunduran dalam pengembangan intelektual karena di kalangan umat Islam sendiri telah terjadi kelesuan berfikir, di mana hal tersebut diindikasikan dengan adanya pendapat di kalangan umat Islam bahwa pintu ijtihad telah tertutup. Implikasi negatif dan hal tersebut adalah munculnya sikap taklid kepada pendapat lama, sehingga umat Islam menjadi statis. Kondisi tersebut menyebabkan setiap perubahan yang secara alamiah dibawa oleh zaman selalu ditentang secara apriori oleh umat Islam.

Hal lain yang menurut Harun ikut berperan dalam mendukung kemunduran umat Islam adalah tarekat sufi yang banyak tersiar di kalangan umat Islam setelah jatuhnya Baghdad, terutama ajaran "zuhud" yang kemudian difahami sebagai pilihan untuk rela meninggalkan kehidupan duniawi karena mementingkan kehidupan rohani. Ajaran tersebut, menurut Harun, pada gilirannya mengalihkan perhatian umat Islam dari hidup duniawi yang sekarang ke kehidupan di "alam ghaib" nanti. Sehubungan dengan hal tersebut timbullah pemahaman bahwa ajaran mengenai ibadahlah yang dipentingkan.

\section{B. Ide Pembaharuan dan Pengaruh Harun Nasution}

Pembaharuan Islam adalah upaya-upaya untuk menyesuaikan paham keagamaan Islam dengan perkembangan baru yang ditimbulkan kemajuan ilmu pengetahuan dan teknologi modern. Dengan demikian pembaharuan dalam Islam bukan berarti mengubah, mengurangi atau menambah teks dalam al-Qur'an maupun teks dalam Hadits, melainkan hanya mengubah atau menyesuaikan paham atas keduanya sesuai dengan perkembangan zaman. Hal ini dilakukan karena bagaimanapun hebatnya pahampaham yang dihasilkan oleh para ulama atau pakar terdahulu tetap ada kekurangannya dan selalu dipengaruhi oleh kecenderungan ilmu pengetahuan, situasi sosial dan lain sebagainya. Paham-paham tersebut mungkin masih banyak yang relevand an masih dapat digunakan, tetapi mungkin banyak yang tidak sesuai lagi. 
Selain itu pembaharuan dalam Islam dapat juga berarti mengubah keadaan umat agar mengikut ajaran yang terdapat di dalam al-Qur'an dan as-Sunnah. Hal ini perlu dilakukan, karena terjadi kesenjangan antara yang dikehendaki al-Qur'an dengan kenyataan yang terjadi di masyarakat. Al-Qur'an misalnya mendorong umat agar menguasai pengetahuan modern serta teknologi secara seimbang, hidup bersatu rukun dan damai, bersikap dinamis, mencintai kebersihan dan lain sebagainya. Namun kenyataan ummat menunjukkan keadaan yang berbeda, sebagian besar ummat Islam hanya menguasai pengetahuan agama sedangkanilmupengetahuanmoderntidak

dikuasainya, hidup dalam keadaan pertentangan dan peperangan, bersikap diktator, kurang menghargai waktu dan lain sebagainya. Sikap dan pandangan hidup ummat demikian jelas tidak sejalan dengan alQur'an dan as-Sunnah, hal demikian harus diperbaharui dengan jalan kembali kepada dua sumber ajaran Islam yang utama itu. Dengan demikian, maka pembaharuan Islam mengandung maksud mengembalikan sikap dan pandangan hidup ummat agar sejalan dengan petunjul al-Qur'an dan as-Sunnah. Menurut Harun, pembaharuan dalam Islam baru terjadi pada abad moden yaitu dimulai pada abad ke$18 \mathrm{M}$, dan pada masa itu dunia timur yang banyak Islam didominasi Barat. Berbarengan dengan bidang politik dan ekonomi, ummat Islam juga harus menerima persinggungan dengan kebudayaan Barat yang disuguhkan kepada mereka. Karena kebudayaan ummat Islam pada umumnya masih mengalami degradasi, wajar saja jika kebudayaan Barat lebih dominan dan banyak menguasai mereka di segala kehidupan.

Dengan adanya persinggungan dengan kebudayaan Barat itulah, sementara tokoh Islam tergerak melakukan reformasi terhadap ajaran aagama mereka. Mulanya dalam soal sosial, ekonomi, politik dan pertahanan tetapi kemudian merebak ke bidang agama, begitulah yang terjadi di Mesir, Turki dan India. Sedangkan di Indonesia, pembaharuan terjadi setelah pengaruh dari negeri-negeri tersebut menjamah nusantara di abad modern.

Dengan pandangan itulah, Harun menganggap adanya pembaharuan dalam Islam dipicu adanya persinggungan kehidupan ummat Islam dengan kebudayaan Barat yang datang ke daerah-daerah koloni mereka di Timur. Sehingga dia mengartikan pembaharuan dalam Islam dengan pemikiran atau gerakan sementara ummat Islam untuk mengubah adat, pikiran, perbuatan atau institusi mereka dengan suatu yang baru sebagaimana terdapat di dunia Barat abad modern.

Harun sering mengatakan bahwa salah satu sebab kemunduran ummat Islam di Indonesia adalah karena terlalu dominannya Asy'ari yang bersifat jabariyah. Karena itulah Harun menyoroti dan selalu menghubungkan antara peran akal dan wahyu. Akal menurutnya sangat penting dan bebas dalam pandangan al-Qur'an. Karena terlalu mengagungkan peran akal itulah, Harun pernah dijuluki sebagai tokoh neomu'tazilah Indonesia. Sebagai seorang intelektual lulusan Timur Tengah dan Amerika, Harun adalah tipe pemikir Islam ultramodern. Ia berusaha untuk menggabungkan dua kutub ilmu Barat dan Timur, dengan melakukan konsep pembaharuan Ioslam untuk membangun masyarakat Islam Indonesia. ${ }^{2 \mathrm{U}}$

Harun Nasution di dalam peta pemikiran Islam di Indonesia dapat kita lihat pada kalimatnya yang sederhana, tapi amat tegas pengetahuan-pengetahuan dalam bidang keagamaan bukan melulu berdasarkan wahyu, kalimat yang sederhana itu bersifat revolusioner. Pernyataan-pernyataan secara diametral bertentangan dengan kecenderungan pemikiran keislaman yang dominan pada waktu itu, ia seakanakan secara lantang memproklamirkan suatu cara atau bentuk pikiran lain, mendobrak tradisi pemikiran yang menekankan cohesiveness, tidak mengharamkan adanya pertentangan pemikiran, mendorong terciptanya pemikiran yang bersifat individual. ${ }^{21}$

Hal ini dibuktikan dengan mewujudkan tiga langkah yang kerap dikenal sebagai "Gebrakan Harun" diantaranya, yaitu:

1. Meletakkan pemahaman yang mendasar dan menyeluruh terhadap Islam.

Menurutnya dalam Islam terdapat dua kelompok ajaran, yaitu: pertama. Bersifat absolut dan mutlak benar, universal, kekal, tidak berubah dan tidak boleh diubah. Kedua. Bersifat absolut tapi relatif, tidak universal, tidak kekal, berubah dan boleh diubah.

2. Dilakukan disaat menjabat Rektor IAIN Syarif Hidayatullah Jakarta 1973 (kini telah berubah menjadi UIN). Saat itu secara revolusioner dia merombak kurikulum IAIN se-Indonesia. Pengantar ilmu agama dimasukkan dengan harapan akan merubah pandangan mahasiswa. Demikian pula mata kuliah Filsafat, tasawuf, Ilmu Kalam, Tauhid dan metodologi Riret. Menurut dia kurikulum IAIN yang selama ini berorientasi Fiqh harus diubah karena hal tersebut akan membuat pikiran mahasiswa menjadi jumud.

3. Bersama Menteri Agama Harun nasution Mengusahan berdirinya Fakultas Pascasarjana Pada tahun 1982. Menurutnya Indonesia belum ada oraganisasi sosial yang berprestasi melakukan pimpinan umat Islam masa depan.

Harun dikenal sebagai intelektual muslim yang banyak memperhatikan masalah pembaharuan dalam islam dalam arti yang seluas-luasnya, terutama pada

${ }^{20}$ Sholahuddin Hamid, "Seratus Tokoh Islam yang Paling Berpengaruh di Indonesia, (Intimedia Cipta Nusantara, 2003), h. 355

21 Aronim, Ensiklopedi Islam, (Ihtiar Baru Vanhauve, Jakarta 2002), h. 3 
bidang teologi, filsafat dan tasawuf serta berbagai masalah kehidupan muslin lainnya. Seluruh ilmu dan pengalmannya berusaha ia tuangkan dalam aplikasi melalui bidang akademisi sebagai dosen, dekan dan rector di IAIN dengan melakukan nasionalisasi ajaran agama dan islamisasi ilmu-ilmu umum. ${ }^{23}$

Harun sangat tepat jika disebut enmancang perubahandalam tradisi akademik di lingkungan Perguruan Tinggi Islam Indonesia, ia melakukan perubahan sistem pendidikan di IAIN di Indonesia. Ada tiga perubahan dan pembaharuan sistem yang diupayakannya.

1. Merubah System kuliah yang selama ini dinilai feudal, menjadi sesatu yang lebih baik, dengan metode diskusi atau seminar.

2. Merubah daya lisan menjadi budaya tulisan. Harun dengan tekun melihat mahasiswa-mahasiswanya untuk menutlis pemikiran secara rutut dan sistematis. Budaya ini diperkenalkan untuk mengatasi kelemahan dalam budaya lisan. karena tidak semua orang bisa memaparkan ide-ide yang ada dalam pikiran secara runtun dan jelas.

3. Harun memperkenalkan pendekatan pemahaman Islam secara utuh dan univesal. Dominasi pendekatan Fiqh selama ini dalam sistem pengakajian Islam membuat kajian Islam agak mandek.

Maka apa yang dirasakan perlu oleh Harun Nasution dikembangkan dalam stuedi Islam di Indonesia, berbeda apa yang dirasa perlu oleh pembaharuanpembaharuan sebelaumny, yaitu pada umumnya mereka yang telah terlihat dan zaman Indonesia sebelum merdeka dalam pergerakan. Harun percaya pada kemampuan manusia untuk tiba pada yang baik. Ia memang menenkankan tanggung jawab pada manusia, yang hanya bisa dituntut bila memang berdasarkan kemauan dan kemampuan diri, bukan karena terpengaruh oleh orang lain.

menurut Harun bahwa penafsiran dan pemikiran itu tidak bersifat mutlak. Oleh sebab itu, imam besar tidak salah jika menyalahkan sesamanya. Semua dipadang masih dalam kebenaran selama ia tidak bertentangan dengan ajaran dasar Islam sebagai tersebut dalam alQur'an dan Hadits. 25

Islam modernis adalah kelompok ummat Islam yang menghedaki agar ajaran Islam mampu memberikan kontribusi secara nyata dalam memecahkan berbagai masalah sosial sepanjang zaman dan dimanapun. Hal ini penting dilakukan, karena sesuai dengan misi Islam, yaitu untuk memberi rahmat bagi seluruh alam dan sepanjang zaman serta dimanapun. Untuk itu ajaran Islam yang dugali dari al-Qur'an dan Hadis harus ditinjau ulang setiap zamatn untuk dilihat secara kritis apakah pemikiran itu masih cocok atau sudah tertinggal.

Sejalan denganitu maka Islam modernis menghendaki agar pintu ijtihad tetap terbuka, dan umat Islam yang memiliki kemampuan dan kepribadian yang baik agar tidak ragu-ragu untuk berijtihad bagi kepentingan ummat Islam. Dengan cara demikianlah ajaran Islam tetap relevan sepanjang zaman.

Banyaknya persoala yang dihadapi, dan bersama dengan itu kurangnya orangyang ahli dan mempunyai waktu luang, menyebabkn kajian yang terbatas tadi tidak terlalu mengena. Keinginan melihat persoalan secara menyeluruh bgai terhalang oleh kemampuan dan waktu. Agaknya secara menyeluruh Harun Nasution muncul lebih kurang 25 tahun sesudah Indonesia merdeka. Namun perlu segera ditambahkan pada pemikiran terdahulu itu bahwa pengaruhnya pada masyarakat basar sekali. Masyarakat bagai terbawa dalam perubahan pemikiran.

Dalam rangka rukukan keada paham-paham klasik, pengaruh Harun Nasution pada murid-muridny tampak besar. Padahal ia sendiri, sejauh yag dapat diamati, tidak mengharapkan para muridnya menjadi duplikat belaka dan dirinya. Ia mengharapkan para muridnya mandiri, dan bisa pula memberi saham yang besar bagi perkembangan masa depan.

Harun Nasution memberikan sesuatu yang baru dalam perkembangan pemikiran Islam di Indonesia. ia bukan sekedar melanjutkanapa yang berkembang, apalagi karena ia sendiri tidak mengkaji perkembangandi Indonesia itu dengan terperinci. Ia membawa perhatian secar lebih jelas dan tegas kepada perkembangan yang nyata dalam dunia Islam dimasa lalau.

Sebagai kajian akademis, maka dengan sendirinya pasaran pemikirannya terbatas pada IAIN serta cendikiawan dan calon cendikiawan dan perguruan tinggi lain terutama di IAIN. Usaha-usaha studi Islam yang sistematis dan ilmiah yang berkembang dikalangan perguruan tinggi Islam di Indonesia untuk sebagaian besar haruslah dikembalikan keada Harun Nasution. Ketekunannya menyebarkan gagasangagasannya melalui engajaran dan ceramahceramahnya di IAIN bukansaja memberikan dasardasar tradisi ilmiah di dalam studi Islam, tetapi sekaligus mentralisir warna atau pola pikir kecenderungan-kecenderungan pemikir Islam yang bersifat apologetik, pudarnya dikotomi modernisme tradisionalisme di dalam pemikiran Islan, terutama dikalangan IAIN Jakarta adalah salah satu sumbangan konkrit dan kehadiran sosok diri dan pikiran-pikiran Harun Nasution. 27

Untuk melakukan pembaharuan pemikiran Islam di IAIN, Harun mencari akar pembenarannya dalam teologi rasional ala Mu'tazilah dan mengenalknanya
${ }^{23}$ Ibid.h.335

${ }_{24}$ Ibid.h. 3

${ }_{25}$ Ibid. h.93 
kepada masyarakat lewat buku dan pengajarannya di IAIN dan Pascasarjana IAIN. Selama menjadi rektor (1973-19840 dan setelahnya sampai tahun 1990 an, sebagai direktur pada program studi lanjutan pertama yang dibuka di IAIN Jakarta, ia mengembangkan pemikiran Islam rasional dan menjaikan program S1 dan Pascasarjana IAIN Jakarta sebagai agen pembaharuan pemikiran dalam Islam dan tempat penyemaian gagasan-gagasan ke-Islaman yang baru.

Dampak dan usaha yang dilakukan Harun Nasution, terlihat berupa seuasasna kreatifits intelektual yang diciptakan terutama di IAIN Jakarta. Pandangannya tentang perlunya rasionall dalam memahai agama, membekas pada mahasiswa yang belajar di IAIN Jakarta, pada tatanan tertentu ide-ide pemhabaruan tersebut mempertanyakan kembali tentang konsep dan argumen dibalik paham dan praktek keagamaan yang selama ini taken forgranted. Disamping itu, keinginan Harun Untuk mengajarkan agar Ummat Islam terbiasa dengan perbedaan pendapat, sering berhadapan dengan paham keislaman di daerah yang belum siap dengan paham keagamaan.

pemikiran Harun Nasution berpengaruh dalam semangat dan tradisi IAIN khususnya dijakarta sebabkan beberapa hal; pertama, secara politis pemikiran Islam; kedua, sebagai Rektor dan Derektu Pascasarjana, tentunya sebagai pengajar pada mata kuliah inti untuk pemikiran Islam, Harun mempunyai pengaruh dalam memilih topik tesis/disertai mahsiswa. Seorang alumni Pascasarjana IAIN Jakarta yang sekarang menjadi Rektor II IAIN Antasari Banjarmasin Mengatakan: "Pengaruh Harun Nasution yang membekas pada anak didiknya adalah sikap pribdi beliau dalam keilmuan. Beliau menghargai pendapat yang berbeda, beliaujuga konsisten walaupun terkadang menjadi perbedaan yang sengit. Kalaupun beliau tidak berdebat, sesungguhnya beliau ingin mengorek argumentasi yang dikembangkan oleh mahasisw. Kemudian beliau juga sangat perhatian terhadap kutipan-kutipan yang diambil dari buku orang lain, diceta kebenarannya, sikap yang demikian ini mengimbas kepada kita ketika mengajar kepada mahasiswa.

Demikianlah, bila kita mencoba menela'ah seorang Harun Meski hanya lewat tulisan-tulisannya maka akan terlihat seperti: Pertama, Harun adalah fenomena yang rasional dan ini kelihatannya melandasi seluruh aspek kehidupan; Kedua, Harun lebih banyak berkontemplasi pada hal-hal yang masuk akal, maka tak heran tentunya bila kemudian ia sangat mengidolakan Mu'tazillah ketimbang Asy'aniyah. Pemikiran Harun Nasution sangat berpengaruh terhadap Islam yang ingin membwa ummt Islam kepda ajaran yang sesuai dengan al-Qur'an dan Hadis. Dan membuka kembali pintu ijtihad.

\section{Karya- Karya Harun Nasution}

Disamping sebagai seorang pengajar, Harun Nasution juga dikenal sebagai penulis. Beberapa buku yang pernah ditulis oleh Harun Nasution antara lain:

1. Akal Dan Wahyu Dalam Islam (1981)

2. Filsafat Agama ( 1995)

3. Sejarah Pemikiran Dan Gerakan (1975)

4. Islam Ditinjau Dari Berbagai Aspeknya (1974)

5. Teologi Islam (1977)

Adapun karyanya yang berisi sebagai berikut:

1. Islam Ditinjau Dari Berbagai Aspeknya (1974). Buku ini terdiri dari dua jilid, diterbitkan pertama kali oleh UI-Press, yang intinya adalah memperkenalkan islam dari berbagai aspeknya. Buku ini menolak pemahaman bahwa islam itu hanya berkisar pada ibadat, fikih, tauhid, hadits, dan akhlak saja. Islam menurut buku Harun ini lebih luas dari itu, termasuk di dalamnya sejarah, peradaban, filsafat, mistisisme, teologi, hukum, lembaga-lembaga, dan politik.

2. Teologi Islam: Aliran-Aliran, Sejarah, Analisa, Dan Perkembangan (1977). Buku ini terdiri dari dua bagian. Bagian pertama, mengandung uraian tentang aliran dan golongan-golongan teologi, bukan hanya yang masih ada tetapi juga yang pernah terdapat dalam islam seperti khawarij, murji'ah, qadariah dan jabariah, mu'tazilah, dan ahli sunnah wal jamaa'ah. Uraian diberikan sedemikian rupa, dari masing-masing alairan atau golongan itu, dan mengandung analisa dan perbandingan dari aliran-aliran tersebut. Sehingga dapat diketahui aliran mana yang bersifat liberal, mana yang bersifat tradisional. Buku ini dicetak pertama kali tahun 1972 oleh UI-Press.

3. Filsafat Agama (1978). Buku ini menjelaskan tentang epistemologi dan wahyu, ketuhanan, argumen-argumen adanya tuhan, roh, serta kejahatan dan kemutlakan Tuhan. Buku ini semula diterbitkan bulan bintang.

4. Filsafat Dan Mistisisme Dalam Islam (1978). Buku ini juga merupakan kumpulan ceramah Harun di IKIP Jakarta. Buku ini terdiri dari dua bagian, yakni bagian filsafat islam dan bagian mistisisme islam (tasawuf). Bagian filsafat islam menguraikan bagaimana kontak pertama anatar islam dan ilmu pengetahuan serta filsafat yunani yang kemudian melahirkan filosuf muslim seperti al-Kindi, al-Razi, al-Farabi, Ibn Sina, al-Ghazali, dan Ibn Rusyd. Sedangkan, bagian mistisisme islam menguraikan bagaimana kedudukan islam sebgai upaya mendekatkan diri pada tuhan. Buku ini terbit tahun 1973 0leh bulan bintang, jakarta.

5. Pembaharuan Dalam Islam: Sejarah Pemikiran Dan Gerakan (1978). Buku ini merupakan kumpulan 
ceramah dan kuliah Harun Nasution di berbagai tempat di jakarta tentang aliran-aliran modern dala islam. Membahas tentang pemikiran dan gerakan pmbaharuan islam, yang timbul di zaman yang lazim disebut periode modern dalam sejarah islam. Pembahasannya mencakup atas pembaruan yang terjadi di tiga negara islam, yaitu Mesir (topik intinya: pendudukan Napoleon dan pembaharuan di Mesir, Muhammad Ali Pasya, al-Tahtawi, Jamaluddin al-Afgani, Muhammad Abduh, Rasyid Ridha, murid dan pengikut Muhammad Abduh), Turki, (topik intinya: Sultan Mahmud Ii, Tanzimat, Usmani muda, turki muda, tiga aliran pembaharuan, islam dan nasionalis, dan Mustafa Kemal), dan India-Pakistan (topik intinya: gerakan Mujahidin, Sayyid Ahmad Khan, gerakan Aligarh, Sayyid Amir Ali, Iqbal, Jinah dan Pakistan, Abul Kalam Azad dan nasionalisme India.

6. Akal Dan Wahyu Dalam Islam (1980). Buku ini menjelaskan pengertian akal dan wahyu dalam islam, kedudukan akal dalam Al-Qur'an dan Hadits, perkembangan ilmu pengetahuan dalam islam, dan peranan akal dalam pemikiran keagamaan islam. Uraian tegas buku ini menyimpulkan bahwa dalam ajaran islam, akal mempunyai kedudukan tinggi dan banyak dipakai, bukan dalam perkembangan ilmu pengetahuan dan kebudayaan saja, tetapi juga dalam perkembangan ajaran keagamaan sendiri. Akal tidak pernah membatalkan wahyu, akal tetap tunduk kepada teks wahyu.

7. Muhammad Abdul dan Teologi Rasional Mu'tazilah (1987). Buku ini merupakan terjemahan dalam bahasa Indonesia dari tesis Ph.D. Harun Nasution yang berjudul "The Place of Reason in Abduh's Theology, Its Impact on his Montreal,

Kanada. Buku ini berisi tentang riwayat hidup Muhammad Abduh, filsafat wujud, kekuatan akal, fungsi wahtu, paham kebebasan manusia dan fatalisme, sifat-sifat Tuhan, perbuatan Tuhan dan konsep Iman. Inti buku ini menjelaskan bahwa pemikiran teologiMuhamad Abdul banyak persamaannya dengan teologi kaum Mu'tazilah, bahka dalam penggunaan kekuatan akal, Muhammad Abduh jauh melebihi pemikiran Mu'tazilah.

8. Islam Rasional (1995). Buku ini merekam hampir sluruh pemikiran keislaman Harun Nasution sejak tahun 1970 sampai 1994 (diedit oleh Syaiful Muzani), terutama mengenai tuntutan modernisasi bagi umat Islam. Hal itu menurut Harun, harus diubah dengan pandangan rasional yang sebenarnya telah dikembangkan oleh teologi

Mu'tazilah. Karena itu, reaktualisasi dan sosialisasi teologi Mu'tazilah merupakan langkah strategis yang harus diambil, sehingga umat Islam secara kultural siap terlibat dalam pembangunan dan modernisasi dengan tetap berpijak pada tradisi sendiri. ${ }^{31}$

\section{METODOLOGI}

Dalam suatu penelitian, baik penelitian yang bersifat kuantitatif maupu kualitatif, diperlukan suatu metode dan prosedur penelitian. Metode berasal dari bahasa Yunani "Methodos" artinya cara atau jalan. Metode merupakan cara kerja untukmemahami obyek yang menjadi sasaran ilmu pengetahuanyang bersangkutan. $^{32}$ Menurut Sutrisno Hadi dalam Marzuki, penelitian dapat diartikan sebagai usaha untuk menemukan, mengembangkan dan menguji kebenaran suatu pengetahuan dan usaha yang dilakukan dengan menggunakan metode-metode ilmah. 33

Berdasarkan hal tersebut, metode penelitian yang digunakan pada sebuah proses penelitian merupakan hal yang sangat penting karena dengan metode yang baik dan benar akan mugkinkan tercapainya suatu tujuan penelitian yang bermanfaat.

\section{Jenis Penelitian}

Cara dan jenis penelitian ini termasuk jenis penelitian kepustakaan (library research) ${ }^{34}$. Yaitu menjadikan bahan pustaka sebagai sumber (data) utama, sehingga lebih sebagai penelitian dokumen (documentary research). Penelitian ini juga termasuk dalam katergori historis-faktual, karena yang diteliti adalah pemikiran seseorang. $^{35}$ Dengan demikian, dalam penilitian kepustakaan ini penuli ingin menganalisis pemikiran Harun Nasution tentang pendidikan Islam di Indonesia dan pengaruhnya.

\section{Pendekatan dan Sifat Penelitian}

Sebagai sarana untuk memudahkan analisis data, dalam kajian kepustakaan ini digunakan beberapa pendekatan segingga dapat memperjelas kajian dalam penelitian. Adapun pendekatan yang ada dalam penelitian ini adalah sebagai berikut: a. Pendekatan Historis

Menurut Shiddiqi, karakter yang menonjol dan pendekatan sejarah adalah tentang signifikansi waktu dan prinsip-prinsip kesejahteraan tentang individualitas dan perkembangan. Melalui pendekatan sejarah, peneliti dapat melakukan periodesasi atau derivasi sebuah fakta, dan melakukan rekonstruksi proses genesis: perubahan dan perkembangan.

${ }^{31}$ Abdul Halim, Teologi Islam Rasional, (Ciputat. Jakarta. 2001) hal. 18-22

${ }^{32}$ Koentjoro Ningrat, Metode-Metode Penelitian Masyarakat, (Jakarta: PT. Gramedia, 1989),h.7

${ }^{33}$ Marzuki, Metodelogi Penelitian, (Yogyakarta: Andi Offset, 2002),h.4

${ }^{34}$ Mari Singarimbun, Metode Penelitian Survey,(Jakarta: LP\#ES, 1989),h.45

${ }^{35}$ Anton Bakker, Metode-Metode Filsafat, (Jakarta: Ghalia Indonesia, 1984),h. 136

${ }^{36}$ Imam Suprayogo dan Tobroni, Metode Penelitian

Sosial-Agama,(Bandung: Remaja Rosdakarya, 2001),h.53 
Dalam hal ini pendekatan historis dilakukan agar tergali bagaimana perjalanan dan bentuk pendidikan Islam hasil dan pemikiran Harun Nasution. b.

\section{Pendekatan Sosiologis}

Sosiologis merupakan suatu kajian ilmiah tentang tingkah laku manusia dalam hubungannya dengan kelompok-kelompok yang lain serta dengan orangorang lain dengan siapa ia berinteraksi. ${ }^{37}$ Dalam penelitian ini, pendekatan sosiologis digunakan untuk memahami bagaimana sosok sang tokoh, yaitu Harun Nasution dan Kiprahnya.

Adapun sifat dan penelitian ini adalah deskriptif kualitatif. Pendekatan kualitatif merupakan penelitian yang membutuhkan kedalaman penghayatan terhadap interaksi antara konsep dan analisis mendalam tentang hubungan-hubungan konsep yang dikaji secara empiris. Bogdan dan Taylor dalam Moleong mengatakan bahwa penelitian kualitatif adalah prosedur penelitian yang menghasilkan data deskriptif berupa kata-kata tertulis atau lisan dan orang-orang dan perilaku yang diamati.

Berdasarkan hal tersebut diatas, penelitian ini mengarah pada mendiskripsikan pemikiran Harun Nasution tentang pendidikan Islam di Indonsia dan pengaruhnya, mulai dari biografi, perjalanan intelektual serta pluralisme dan humanisme keagamaan yang diaplikasikan oleh Harun Nasution di Indonesia.

\section{Metode Pengumpulan Data}

Penelitian ini merupakan penelitian kepustakaan dan sumber yang digunakanterdiri dari sumber primer dan sumber sekunder, maka data yang digunakan dalam penelitian diperoleh dari literatur-literatur, dokumendokumen atau transkip yang membahas tentang pendidikan Islam. Penelitian melakukan pengumpulan literatur dan buah pemikiran Harun Nasution yang membahas tentang pendidikan Islam di Indonesia utnuk dijadikan bahan primer.

Selanjutnya, menurut Scarzman dan Strauss dalam Dedy Mulyana menegaskan bahwa dokumen historis merupakan bahan penting dalam penelitian kualitatif. Menurutnya, sebagai bagian dari metode lapangan (field method), peneliti dapat menelaah dokumen historis dan sumber-sumber sekunder lainnya. Kebanyakan situasi yang dikaji mempunyai sejarah dan dokumen-dokumen ini sering menjelaskan aspek situasi tersebut. Dalam kaitan ini berupa; autobiografi, catatan harian dan surat-surat pribadi biasanya merupakan hal yang terpenting.

adapun untuk mendapatkan data yang relevan dengan permasalahan yang penulis kemukakan dalam

\footnotetext{
${ }^{37}$ Wila Huky, Pengantar Sosiologi, (Surabaya: Usaha Nasional, 1986),h.30

${ }^{38}$ Lexy J.Moleong, Metode Penelitian Kualitatif Edisi Revisi,(Bandung: Rosda Karya, 2011),h.4

39 Deddy Mulyana, Metode Penelitian kualitatif: Paradigma Baru Ilmu Komunikasi dan Ilmu Sosial

penelitian ini dapat dilakukan dengan menggunakan data primer dan sekunder, ${ }^{40}$ adalah:

a. Data Primer

Merupakan data yang diambil dan pemikiran Harun Nasution secara langsung yang telah tertuang dengan bentuk tulisan-tulisan, baik berupa buku yang ia tulis sendiri maupun yang diedit oleh orang lain, artiker, makalah dan tulisan-tulisan ilmuah lainnya.

b. Data Sekunder

Merupakan sumber data yang tidak dibatasi ruang dan waktu. ${ }^{41}$ Maksudnya, jenis informasi atau data sudah tersedia sehingga penulis tinggal mengambil, mengumpulkan dan mengelompokkan data. Dalam penelitian ini penulis mengambil data sekunder dan ensikiopedi, kamus, majalah, makalah dan website yang dihasilkan oleh pemikir lain, baik yang berbicara tentang pemikiran Harun Nasution

maupun gagasan mereka sendiri yang membicarakan masalah yang terkait dalam penelitian ini. sehingga dapat membantu memecahkan permasalahan yang menjadi fokus peneletian tesis ini.

Berdasarkan uraian di atas, metode yang digunakan dalam pengumpulan data-data tersebut ialah metode dokumentasi, yaitu suatu cara pengumpulan data dengan mencari data mengenai hal-hal atau variabel yang berupa teks, catatan trasnkip, bahan-bahan dan lain sebagainya.

\section{Teknik Analisa Data}

Setelah data-data penelitian, maka langkah selanjutnya adalah menentukan metode analisis. Metode analiss yang digungakan ialah content analysis (analisis isi), yaitu upaya menafsirkan ide atau pemikiran dari seorang tokoh yang benama Harun Nasution tentang pendidikan Islam di Indonsia dan pengaruhnya, yang kemudian ide-ide tersebut dianalisis secara mendalam dan seksama guna memperoleh nilai positif untuk menjawab masalah krusial pendidikan Islam saat ini. Dengan menggunakan motode content analysis.

\section{Teknik Penjamin Keabsahan Data}

Teknik untuk mencapai keabsahan atau kredibilitas data dilakukan dengan cara mengambil keputusan dan verifikasi. $^{43}$ Dalam hal ini verifikasi dapat dilakukan dengan singkat yaitu dengan cara mengumpulkan data-data baru yang berkaitan dengan gagasan Harun Nasution tentang pendidikan Islam di Indonesia dan pengaruhnya. Beberapa usaha agar uji keabsahan data tersebut dapat dipenuhi penulis melakukan triangulasi. Menurut Sugiyono, tenik triangulasi adalah pengujian

\footnotetext{
${ }^{40}$ S. Margono, Metode Penelitian Pendidikan, (Jakarta: Rineka Cipat, 2003),h.23

${ }^{41}$ James A. Black, Metode dan masalah Penelitian

Sosial, (Bandung: Refika Aditama, 2001),h.348

${ }^{42}$ Suharsimi Arikunto, Prosedur Penelitian Praktis

(Jakarta; Bina Aksara, 1983),h.132

${ }^{43}$ Amirul Hadi dan Haryono, Metode Penelitian

Pendidikan, (Bandung: Pustaka Setia, 1998), cet. Ke-1,h.62
} 
kreadibilitas dengan melakukan pengecekan data dan berbagai cara, sumber dan waktu. ${ }^{44}$ Proses triangulasi yang penulis lakukan pada penelitian ini dengan cara memeriksa kebenaran data yang diperoleh kepada pihak lain yang dapat dipercaya. Kemudian dalam penelitian ini juga digunakan triangulasi sumber. Triangulasi sumber untuk menguji kredibilitas data dilakukan dengan cara mengecek data yang telah diperoleh melalui beberapa sumber.

\section{HASIL DAN PEMBAHASAN}

\section{A. Pemikiran Harun Nasulion tentang Ilmu Keislaman}

Harun Nasution adalah seorang figur yang dapat dicatat dalam sejarah Islam Indonesia, sebab dengan pemikiran-pemikiran rasionalnya Harun mencoba untuk menghilangkan salah satu sebab kemunduran umat Islam, yaitu dominasi Asy'ariyah yang sangat bersifat Jabariyah (terlalu mengarah kepada takdir) atau faham fatalisme. Sebagai usaha ke arah itu,

Harun dalam berbagai tulisannya selalu menghubungkan akal dengan wahyu dan lebih tajam lagi melihat fungsi akal itu ke dalam pandangan alQur'an yang demikian penting dan bebas.

Di samping itu, Harun Nasution juga merupakan sumber inspirasi dan semangat bagi perkembangan kajian Islam di Indonesia. Harun adalah tokoh yang menghabiskan segenap umumya untuk peningkatan kualitas lembaga pendidikan tinggi Islam di Indonesia. Atas dasar ini, sangat beralasan dan sejalan apa yang diusulkan Menteri Pendidikan Nasional, A. Malik Fajar, agar Harun Nasution diusulkan menjadi tokoh pendidikan di bidang Islamic Studies. Tokoh pengagas Islam rasional ini, sangat layak mendapatkan itu, karena karya dan hasil kerjanya sangat nyata, yaitu semacam tradisi intelektual di mana orang berani berdebat secara terbuka, berani mempertanyakan suatu yang sementara ini dianggap mapan.

Untuk mengembangkan buah pemikirannya, agar Islam diajarkan komprehensif dan terpadu, Harun menulis menulis berapa buku, yang kemudian menjadi teks book bagi semua mahasiswa IAIN, menurut Harun pengajaran Islam dan keislaman di IAIN masih terbatas hanya pada pengajaran agama yang fiqh oriented. $^{46}$ Di samping itu pengajaran agama baik filsafat, tasawuf maupun sejarah terbatas pada pemikiran tokoh-tokoh tertentu saja. Pemahaman Islam yang demikian itu hanya akan menghasilkan

\footnotetext{
${ }^{44}$ Sugiyono, Metode Penelitian Pendidikan

Kualitatif, Kuantitatif dan $R \& D$...,h.372

${ }^{45}$ Sugiyono, Metode Penelitian Pendidikan Kualitatif , Kuantitatiffan $R \& D$..

${ }^{46}$ Saiful Muzani, Mu"tazilah and the Modernization of the
} Indonesian Muslim Community: Intelektual Potrait of Harun Nasution, Studia Islamica Vol 1 No. 1 (1994), 104 dalam Fuad Jabali dan Jamhari, IAIN, Modernisasi Islam di Indonesia (Jakarta: Logos, 2002), 42. mahasiswa yang mempunyai pikiran partial dan hanya melihat Islam secara sempit saja. Oleh karena itu Harun mengusulkan untuk membuat suatu teks book yang melihat Islam dalam paradigma yang benar. Usul Harun untuk pengenalan Islam secara komprehensif, dengan melihat Islam dari berbagai aspeknya diintegrasikan ke dalam kurikulum nasional untuk

pengajaran Islam. Hal ini ditemukan dalam wawancara berikut:

"Pak Harun Nasution mengusung gagasan Islam Rasional yang menitik beratkan apa yang dimaksud dengan wahyu dan Iman manusia. Wahyu adalah tanda keadilan Allah, kebaikan dan kewajiban Allah terhadap manusia, maka dari sudut manusia, Iman adalah tanggapan manusia mengenai wahyu Tuhan. Karena itu, wahyu dan iman merupakan dua entitas yang saling menanggapi. Wahyu Tuhan baru benarbenar mempunyai arti jika ditanggapi oleh Iman manusia. 47

Pandangan Harun tentang perlunya berfikir rasional dalam memahami agama, pada tataran tertentu mempertanyakan kembali tentang konsep dan argumen dibalik paham dan praktek keagamaan yang selama ini taken for granted. Di samping itu keinginan Harun untuk mengajarkan agar umat Islam terbiasa dengan perbedaan pendapat bahwa ternyata Islam

mempunyai bermacam-macam aspek, sering berhadapan dengan paham keislaman atau pemahaman keislaman yang belum siap menerima keragaman paham keagamaan paham keagamaan yang berkembang.

Sebagai lembaga pengkajian Islam paling advance dan merupakan agen bagi perubahan masyarakat Islam, maka masyarakat mempunyai harapan yang sangat besar terhadap pemikiran Islam di IAIN. Untuk mengejawantahkan harapan masyarakat tersebut IAIN hendaknya menjabarkan pemikiran Islam ke tengah masyarakat dengan cara menyebarkan Islam. Sebagai pedoman dalam berbagai aspek kehidupan umat Islam, agar mereka meraih kemajuan membuat masyarakat lebih taat menjalankan ajaran agama Islam, dapat mendatangkan kesejukan bagi umat beragama, serta menjadi panutan dalam kehidupan.

Dalam banyak kesempatan Harun seringkali menekankan kalimat "Islam dengan pengertian sebenarnya". Seolah-olah Harun ingin menyatakan bahwa pengertian Islam yang kita pahami selama ini bukan menurut arti yang sebenarnya. Misalnya dalam persoalan antara sains dan agama, Harun melihat antara keduanya tidak ada pertentangan. Agama berisi dogma yang tidak berubah dan tidak terbatas. Sedangkan sains memiliki perbatasan, meskipun tidak memiliki batas-batas dan tidak ada batasnya. Perbatasan yang dimaksud adalah titik terakhir yang

\footnotetext{
${ }^{47}$ Ali Mufradi, Wawancara, PPs. IAIN Sunan Ampel Surabaya, 31 Mei 2010.

${ }^{48}$ Fuad Jabali dan Jamhari, 43.
} 
dapat dicapai. Karena firman-firman Allah yang di zaman klasik dipegang secara konsisten, maka pengetahuan Allah itu begitu rupa, sehingga kalau seluruh lautan itu dijadikan tinta, dan seluruh pepohonan beserta ranting dan cabangnya dijadikan pena, untuk menuliskan pengetahuan Allah, maka pengetahuan Allah, maka pengetahuan Allah Swt tidak akan habis karena batasnya ada pada Allah tidak terbatas.

\section{Sekilas tentang Islam Rasional \\ a. Pengertian Islam Rasional}

Islam Rasional merupakan salah satu corak paham keIslaman yang dimuat sebagian kecil masyarakat muslim Indonesia, yaitu oleh mereka yang memiliki latar belakang pendidikan tinggi, atau oleh mereka yang mempelajari Islam pada Perguruan Tinggi di Barat. Keberadaannya sering dicurigai, karena dikhawatirkan akan membawa paham keislaman yang didasarkan kepada kemauan akal pikirannya semata, atau menafsirkan ajaran al Qor'an dan al Sunnah menurut kehendak hatinya.

Secara global, Islam adalah ajaran yang diwahyukan Tuhan kepada Nabi Muhammad SAW dengan tujuan memberikan petunjuk kepada manusia untuk hidup bahagia di dunia dan akhirat. Sedangkan kata rasional, berasal dari bahasa Inggris, rational,yang berarti masuk akal, berakal. ${ }^{51}$ Kata rasional selanjutnya dapat berarti pemikiran, pandangan, dan pendapat yang sejalan dengan pendapat akal. Sedangkan pengertian dari akal dapat berarti daya berpikir yang ada dalam diri manusia dan merupakan salah satu daya dari jiwa serta mengandung arti berpikir, memahami dan mengerti. ${ }^{52}$ Kata akal berasal dari bahasa Arab, yaitu aqala, yang berarti mengikat dan menahan. Pada zaman jahiliyah orang yang berakal (,,aqil) adalah orang-orang yang dapat menahan amarahnya dan mengendalikan hawa nafsunya, sehingga dapat mengambil tindakan yang bijaksana dalam menghadapi persoalan. ${ }^{53}$

Secara terminologis dapat dikatakan bahwa yang dimaksud rasional adalah sesuatu yang masuk akal. Rasional dapat juga berarti potensi rohaniah sehingga manusia dapat membedakan antara yang benar dan yang salah. Isalam rasional adalah Islam yang dalam menjelaskan ajaran-ajarannya tidak hanya mengandalkan pendapat wahyu, tetapi juga

\footnotetext{
${ }^{49}$ Nurcholis Madjid, Mengambil Ilmu dan Moral Harun Nasution. dalam Abdul Halim (ed) Teologi Islam Rasional, Apresiasi terhadap Wacana dan Praksis Harun Nasution (Jakarta: Ciputat Press, 2001), 78-79.

50 Abudin Nata. 2001. Peta Keragaman Pemikiran Islam di Indonesia.(Jakarta: Raja Grafindo Persada) hlm. 59 th. 2001.

51 John M. Echols dan Hassan Shadily. 1979. Kamus Inggris Indonesia. (Jakarta: Gramedia) cet. VIII. HIm. 466 th. 1974

${ }^{52}$ Kafrawi Ridwan, dkk. 1999. Ensiklopedi Islam. (Jakarta: Gramedia) cet. IX. hlm. 98 th. 1999

Ibid,. hlm. 98
}

mengikutsertakan akal pikiran. Islam rasional juga berarti Islam yang menghargai pendapat akal pikiran dan menggunakannya untuk memperkuat dalil-dalil ajaran agama. Dan juga berarti Islam yang menjelaskan hikmah filosofi dari suatu teks atau perintah atau larangan yang terdapat dalam wahyu. Misalnya Allah SWT memerintahkan shalat, maka akal digunakan untuk mencari hikmah yang terdapat dalam perintah shalat. ${ }^{54}$

\section{b. Ciri-ciri Islam rasional}

Islam rasional memiliki ciri-ciri sebagai berikut: ${ }^{55}$

1) Menggunakan akal pikiran dalam memperkuat argumen ajaran-ajaran agaa yang dimajukannya, tanpa meninggalkan wahyu.

2) Selalu mencari hikmah yang dapat diterima akal dari suatu ajaran agama.

3) Islam rasional selalu berpikir sistematik, radikal dan universal.

4) Selalu bertanya dengan menggunakan pertanyaan mengapa.

5) Pemikirannya sejalan dengan hukum-hukum Tuhan yang ada di alam.

6) Mencari penyesuaian antara pendapat akal dengan pendapat wahyu.

7) Hasil pemikiran akal dianggap bukan sesuatu yang final, melainkan hanya sementara. Untuk itu pintu ijtihad tidak pernah tertutup.

Mereka yang memiliki sifat-sifat demikian itu, dapat dikatakan sebagai Islam rasional.

\section{Pendekatan Islam Rasional Harun Nasution c. Kodifikasi aliran teologi Islam.}

Berbicara tentang teologi tentunya kita sedang berbicara minimal menyangkut empat hal diantaranya adalah ; kekuasaan, kehendak mutlak tuhan, keadilan tuhan, perbuatan tuhan dan yang terakhir adalah takdir dan sunnatullah. ${ }^{56}$

Pembahasan-pembahasan yang pernah mengemuka dalam Islam, terutama pada awal-awalnya, lebih disebabkan oleh keadaan ketidak puasan sekelompok masyarakat muslim, terhadap proses tahkim atau albitrase, ekses dari keadaan inilah yang telah memaksa golongan tertentu untuk mengunakan logika dan pembenaran perbuatan, pandangannya dengan menggunakan alqur'an serta menghukum kelompok diluar mereka, perseteruan penjang ini telah melahirkan berbagai kelompok dan sekte-sekte dengan pemikiran dan pendangan-pandangan mereka yang khas. Diantara kelompok-kelompok itu adalah:

\footnotetext{
${ }^{54}$ Abudin Nata. Op. Cit. hlm. 62

55 Ibid., hlm. 62-63
}

56 T. Bahrun. Harun Nasution :Teolog Pembaharu http://www.scribd.com/doc/ 19682920/ Harun-Nasution-TeologiPembaharuan. di akses tanggal 1 Juni 2011.

${ }^{57}$ Harun Nasution. Teologi Islam:.(Jakarta : UI Press) hlm.7 th. 1986 


\section{1) Khawarij}

Khawarij adalah kelompok pertama pada mulanya khawarij mempersoalkan tentang Imamah tetapi pada akhirnya tidak lagi mempersoalkan tentang Imamah akan tetapi mereka telah memasuki persoalan teologi dimana Khawarij mempertanyakan tentang siapakah yang disebut mukmin dan siapa pula yang disebut dengan kafir dan siapa pula yang masih dalam Islam dan tidak, karena menurut Khawarij orang yang melakukan dosa besar dapat dianggap kafir.

\section{2) Murji'ah}

Kelompok ini kembali menegaskan bahwa manusia yang berbuat dosa besar tetap diakui sebagai mukmin bukan kafir, menyangkut dosa yang ia lakukan mereka beranggapan itu adalah hak Tuhan untuk mengampuni atau tidak.

\section{3) Mu'tazilah}

Ini adalah golongan yang sangat luar biasa diyaman, mu'tazilah menganggap bahwa orang yang melakukan dosa besar bukan Islam dan juga bukan kafir tetapi orang-orang tersebut berada diantara mukmin dan kafir sehingga mereka berpendapat bahwa diakhirat akan ada tempat diantara syurga dan nereka untuk pelaku dosa besar populernya tempat tersebut dianamakan al manzila bain al manzilatain.

\section{4) Qadariah}

Kelompokqadaria mengatakan bahwa tiap manusia bebas bertindak menurut mereka sendiri tidak ada campur tangan Tuhan sehingga dalam bahasa Inggris dikenal dengan istilah, Free will dan free act. Ini merupakan konsep manusia menurut golongan Qadariah.

\section{5) Jabariah}

Jabariah memiliki ideology bahwa, manusia tidak memiliki hak dan kemampuan sebagaimana yang dikemukakan oleh Qadariah, akan tetapi menurut Jabariah bahwa segala tindakan dan prilaku manusia adalah paksaan dari Tuhan.

\section{a. Teologi Islam dan Upaya Peningkatan Produktivitas}

Dalam agama terdapat dua ajaran yang erat kaitannya dengan produktivitas. Pertama, agama mengajarkan bahwa sesudah hidup pertama di dunia yang bersifat material ini, ada hidup kedua nanti di akhirat yang bersifat spiritual. Bagaimana ajaran ini terhadap produktivitas dari penganut agama bersangkutan sangat bergantung dari kedua corak hidup tersebut. Apabila kehidupan duniawi dipandang penting, maka produktivitas akan meningkat. Tetapi, sebaliknya, kalau hidup akhirat yang diutamakan, produktivitas akan menurun. Kedua, agama memiliki ajaran mengenai nasib dan perbuatan manusia. Kalau nasib manusia telah ditentukan Tuhan sejak semula, dalam arti bahwa perbuatam manusia adalah ciptaan Tuhan. Maka produktivitas masyarakat yang menganut paham keagamaan seperti demikian akan sangat rendah sekali. Tetapi dalam masyarkat yang menganut paham bahwa manusialah yang menciptakan perbuatannya, produktivitas akan tinggi. Paham pertama dikenal dengan filsafat fatalisme (Jabariyah) dan paham kedua disebut Qodariyah atau kebebasan manusia dalam kemauan dan perbuatan.

Al-Qur'an sendiri mengandung arti ajaran-ajaran yang dapat melahirkan baik filsafat fatalism (Jabariyah) maupun Qodariyah. Yang dapat membawa orang pada faham fatalism dapat ditemukan misalnya pada ayatayat berikut :

Tiada suatu bencanapun yang menimpa di bumi dan (tidak pula) pada dirimu sendiri melainkan telah tertulis dalam kitab (Lauhul Mahfuzh) sebelum Kami menciptakannya (QS. Al Hadid:22)

Maka (yang sebenarnya) bukan kamu yang membunuh mereka, akan tetapi Allahlah yang membunuh mereka, dan bukan kamu yang melempar ketika kamu melempar tetapi Allah-lah yang melempar (QS AlAnfal:17)

Sementara itu yang dapat membawa orang pada paham Qodariyah, dapat dilihat missal dalam ayat berikut :

Dan katakanlah : "Kebenaran itu datangnya dari Tuhanmu, maka barangsiapa yang ingin (beriman) hendaklah ia beriman, dan barangsiapa yang ingin (kafir) biarlah ia kafir" (QS Al Kahfi:29)

Pada sejarah Islam, yang bisanya dibagi ke dalam tiga periode yakni periode Klasik (650-1250 M) Periode pertengahan (1250-1800) dan Periode Modern (1800seterusnya). Kedua macam ajaran pernah mempengaruhi Islam untuk masa tertentu.

\section{Periode Klasik}

Pada Periode Klasik berkembang teologi sunnatullah. Sunnatullah adalah hukum alam, yang di barat disebut dengan natural laws. Bedanya natural laws adalah ciptaan alam, sedangkan sunnatullah adalah ciptaan Tuhan.

Ciri-ciri Teologi Sunnatullah adalah:

a. Kedudukan akal yang tinggi.

b. Kebebasan manusia dalam kemauan dan perbuatan

c. Kebebasan berfikir hanya diikat oleh ajaranajaran dasar Al-Qur'an dan hadis yang sedikit sekali jumlahnya.

d. Percaya adanya sunnatullah dan kausalitas

e. Mengambil arti metamorphosis dari teks wahyu

f. Dinamika dalam sikap dan berfikir.

Ulama Periode Klasik itu memakai metode berfikir rasional, ilmiah dan filosofis. Dan yang cocok dengan metode berfikir ini adalah filsafat Qodariyah, yang 
menggambarkan kebebasan manusia dalam kehendak dan perbuatan. Oleh kerena itu sikap umat Islam zaman itu adalah dinamis, orientasi dunia mereka tidak dikalahkan oleh orientasi akhirat. Keduanya berjalan berimbang. Tidak mengherankan kalau pada periode klasik itu, soal dunia dan akhirat sama-sama dipentingkan, dan produktifitas meningkat pesat.

Sekiranya ulama Islam pada zaman klasik itu hanya berorientasi pada akhirat saja, tanpa orientasi dunia, dan memakai filsafat fatalisme (Jabariyah), kemajuan dalam berbagai bidang tidak akan tercapai. Teologi sunnatullah dengan filsafat Qodariyahnya serta orientasi duniawi disamping akhirat, juga membuat umat Islam produktif dalam bidang ekonomi dan peradaban pada zaman klasik tersebut. Mesir, Suriah, Irak dan Persia pada waktu itu menjadi pusat perdangangan di Timur Tengah.

Kemajuan juga ada dalam bidang pertanian. Pada periode klasik ini, dalam bidang sains juga mengalami kemajuan yang pesat. Ilmu kedokteran, Kimia, Matematika, Astronomi dan ilmu-ilmu lain. Ulamaulama klasik bukan hanya produktif dalam soal keduniaan. Sejalan dengan sikap tidak meninggalkan hidup spiritual, ilmu agama juga berkembang pada zaman itu, seperti Ilmu Tafsir, Fiqih, Akidah, Tasawuf dan lan-lain.

Demikianlah teologi sunnatullah zaman klasik dengan pemikiran rasional agamais, filosofis dan ilmiahnya, yang membuat ulama dan umat Islam produktif dalam hidup keduniawian di bidang politik, ekonomi, industry, pertanian, sains. Juga produktif dalam bidang hidup keakhiratan di bidang akidah, teologi, tafsir, filsafat, tasawuf dan lain-lain.

\section{Periode Pertengahan}

Teologi sunnatullah dengan pemikiran rasional, filosofis dan ilmiah zaman klasik tidak dapat dipertahankan oleh umat Islam dan gantikan oleh teologi kehendak mutlak Tuhan (Jabariyah atau Fatalisme) yang besar pegaruhnya bagi umat Islam di dunia, mulai dari pertengahan abad 12 sampai zaman kita sekarang ini.

Ciri-ciri teologi fatalisme itu adalah:

a. Kedudukan akal yang rendah

b. Ketidak bebasan manusia dalam kemauan dan perbuatan.

c. Kebebasan berpikir yang diikat banyak dogma.

d. Ketidak percayaan pada sunnatullah dan kausalitas.

e. Terikat pada arti tekstual dari Al-Quran dan Hadis.

f. Statis dalam sikap dan berfikir.

Sikap-sikap yang dimiliki oleh orang-orang berteologi fatalisme itu mempengaruhi umat secara umum. Di kalangan mereka terdapat sikap lebih mementingkan hidup spiritual dan sikap tawakal serta menunggu dengan sabar datangnya rahmat Tuhan. Sikap ini di kalangan awam di perkuat lagi oleh paham fatalisme dengan teologi kehendak mutlak Tuhan. Akibatnya berbagai sektor yang sebelumnya sangat maju pada periode klasik menjadi sangat mundur. Produktifitas ulama dan umat Islam periode pertengahan statis jalan ditempat.

\section{Periode Modern}

Abad ke 19, dimana orang Eropa yang dahulu mundur sekarang terlah maju itu, datang ke Dunia Islam. Dunia Islam terkejut dan tidak menyangka bahwa Eropa yang telah mereka kalahkan pada Periode Klasik dahulu, pada zaman modern menguasai mereka. Kerajaan Turki Utsmani, adikuasa pada zaman pertengahan mulai mengalami kekalahankekalahan dalam peperangannnya di Eropa. Napoleon Bonaparte dalam waktu tiga minggu mampu menguasai seluruh Mesir pada 1798 M. Inggris memasuki India dan menghancurkan kerajaan Mughal pada $1857 \mathrm{M}$.

Hal ini membuat ulama-ulama abad ke 19 merenungkan apa yang perlu dilakukan umat Islam untuk mencapai kemajuan kembali seperti zaman Islam klasik dulu. Maka lahirlah tokoh pembaharuan di Mesir seperti Al-Thahtawi, Jamaluddin Al Afgani dan Muhammad Abduh. Di Turki ada Mehmet Shidik Rifat, Nemik Kamal dan Zia Gokalp. Di India seperti Ahmad Khan, Ameer Ali. Pakistan ada Muhammad Iqbal. Semua pembaharu ini berpendapat bahwa untuk mengejar ketertinggalan umat Islam harus menghidupkan lagi pemikiran rasional agamis zaman klasik dengan perhatian yang besar pada sains dan teknologi.

\section{Islam Rasional Harun Nasution}

Apa yang menjadi dasar atau latar belakang bagi Harun Nasution, tentang pentingnya perubahan konsep teologi yang dianut dan difahami oleh masyarakat Indonesia saat ini, apakah konsep teologi yang umumnya diyakini oleh sebagian besar umat Islam Indonesia tidak relevan lagi.

Dari beberapa karya Harun Nasution tentang pentingnya perubahan pemahaman teologi umat Islam Indonesia adalah dikarenakan konsep teologi yang umumnya difahami oleh masyarakat Indonesia telah menyebabkan masyarakat Indonesia lemah dan malas dalam produktifitas, ini dikarenakan pemahaman tentag konsep kekuasaan tuhan yang absolut yang merupakan ajaran teologi asya'ariyah, dengan alasan ini Harun Nasution mencoba mengubah pemahaman ini dengan pendekatan teologi yang dikembangkan oleh golongan mu'tazilah, dimana menurut golongan mu'tazilah bahwa manusia mempunyai kekuasan dan kemampuan untuk memanfaatkan segala potensi yang 
dimilikinya dengan menggunakan kemampuan fikir dan olah budi dengan alasan ini, diharapkan manusia Indonesia tidak berpangku tangan menerima nasib namun mencoba merubah nasib itu dengan usaha sungguh-sungguh, sebab manusia bisa berhasil dengan kemampuannya yaitu kemampuan untuk berpikir dan berkarya.

Harun Nasution adalah sosok seorang intelektual muslim yang terkenal sangat rasionalis. Hal itu tercermin dalam pandangan-pandangannya, seperti; bagaimana membawa umat Islam khususnya di Indonesia kearah rasionalitas, dan bagaimana agar di kalangan umat Islam Indonesia itu tumbuh kapasitas pengakuan terhadap manusia qadariyah. ${ }^{62}$ Harun sering menyatakan bahwa salah satu sebab kemunduran umat Islam Indonesia adalah akibat dominasi Asy'arisme yang sangat bersifat Jabariah (terlalu menyerah pada takdir). Dua pertanyaan tersebut cukup menjadi alasan tentang pandanganpandangan rasional Harun Nasution. Faham rasional ini terlihat dalam beberapa tulisan Harun yang menyatakan, bahwa dinamika di kalangan umat Islam itu harus dihidupkan kembali dengan cara menjauhkan diri dari faham zuhud, yaitu faham yang meninggalkan hidup duniawi dan mementingkan hidup rohani yang banyak terdapat dalam aliran tarekat sufi yang mengalihkan perhatian umat Islam dari kehidupan duniawi kepada kehidupan alam gaib. Kecuali itu umat Islam harus pula menjauhkan diri

dari faham tawakkal dan faham jabariyah, mengembalikannya ke teologi yang mengandung paham dinamika dan kepercayaan kepada rasio dalam batas yang ditentukan oleh wahyu, serta harus

dirangsang untuk berfikir dan banyak berusaha.

Harun menambahkan, bahwa teologi kehendak mutlak Tuhan dengan pemikiran tradisional, non filosofis dan non ilmiah, telah begitu besar mempengaruhi terhadap umat Islam Indonesia sejak semula. Banyak umat Islam Indonesia yang sangat percaya bahwa, nasib secara mutlak itu terletak ditangan Tuhan, manusia tidak berdaya dan hanya menyerah kepada qadha dan qadar Tuhan. Karena berkembangnya teologi kehendak mutlak Tuhan ini, banyak umat Islam yang ragu-ragu dan kurang percaya akan adanya sunatullah, maka usaha manusiapun tak banyak artinya, usahapun hanya sedikit dijalankan dan $d o$ " $a$ yang diperbanyak. Yang pasti sikap serupa ini tidak banyak menolong bagi meningkatnya produktifitas.

Harun Nasution mengusung gagasan Islam rasional yang menitik beratkan apa yang dimaksud dengan wahyu dan iman manusia. Wahyu adalah tanda

62 Dewan Redaksi. 2001. Ensiklopedi Islam. (Jakarta: PT Ichtiar Baru Van Hoeve) Cet. Ke-9. Hlm. 20 th. 2011

63 Harun Nasution. 1992. Pembaharuan Dalam IslamSejarah Pemikran dan Gerakan. (Jakarta : Bulan Bintang). Cet. Ke 9. Hlm. 201 th. 1992

${ }^{64}$ Saiful Muzani, Islam Rasional, Op.Cit., hlm.120. keadilan Tuhan, kebaikan dan kewajiban manusia, maka dari sudut manusia iman adalah tanggapan manusia mengenai wahyu Tuhan. Karena itu, wahyu dan iman merupakan dua entitas yang saling menanggapi. Wahyu Tuhan baru benar-benar mempunyai arti jika ditanggapi oleh iman manusia. 65 Sementara itu, dalam mengembangkan paham rasionalnya, Harun Nasution menunjukkan bahwa al Qur'an sangat menghargai akal pikiran. Kemunduran umat Islam di Indonesia antara lain disebabkan karena paham taklid, yakni mengikuti pendapat orang lain secara pasif. Paham ini yang menyebabkan umat Islam statis, tidak kritis, dan kurang menghargai ilmu pengetahuan. ${ }^{66}$ Untuk itu, dalam berbagai tulisannya Harun selalu menghubungkan akal dengan wahyu, dan lebih tajam lagi melihat fungsi akal itu dalam pandangan Alquran yang demikian penting dan bebas.

\section{a. Pentingnya Akal}

Akal, menurut Muhammad Abduh, adalah suatu daya yang hanya dimiliki manusia, dan oleh karena itu dialah yang memperbedakan manusia dari makhluk lain. Akal adalah tonggak kehidupan manusia dan dasar kelanjutan wujudnya. Peningkatan daya akal merupakan salah satu dasar pembinaan budi pekerti mulia yang menjadi dasar dan surnber kehidupan dan kebahagiaan bangsa-bangsa.

Keharusan manusia mempergunakan akalnya, bukanlah hanya merupakan ilham yang terdapat dalam dirinya, tetapi juga adalah ajaran AI-Qur'an. Kitab suci ini, kata Muhammad Abduh, memerintahkan kita untuk berpikir dan mempergunakan akal serta melarang kita memakai sikap taklid.

Pendapat ini didasarkan pada Al Qur'an yang banyak menyebutkan tentang pentingnya akal, diantaranya adalah QS al Baqarah: 164

Sesungguhnya pada penciptaan langit dan bumi, pergantian malam dan siang, kapal yang berlayar di laut dengan (muatan)yang bermanfaat bagi manusia, apa yang diturunkan Allah dari langit berupa air, lalu dengan itu dihidupkan-Nya bumi setelah mati (kering), dan Dia tebarkan di dalamnya bermacammacam binatang, dan perkisaran angin dan awan yang dikendalikan antara langit dan bumi, semua itu sungguh, merupakan tanda-tanda (kebesaran Allah) bagi orang-orang yang mengerti. (QS al Baqarah: 164)

Betapa tingginya pengargaan Islam terhadap akal dapat dilihat dari hadits qudsi, yang menggambarkan Tuhan bersabda kepada akal berikut ini.

65 Ahmad Taufik .Sejarah Pemikiran dan Tokoh Modernisme. (Jakarta : Raja Grafindo Persada) Hlm.15 th. 2005

${ }_{67}^{66}$ Abudin Nata. Op. Cit. hlm. 75

${ }^{67}$ Harun Nasution. 1987. Muhammad Abduh dan Teologi Islam Mu"tazilah.(Jakarta : Universitas Indonesia). hlm. 44-46 th. 1987

${ }^{68}$ Ibid hal. 46 
Demi kekuasaan dan keagunganKu, tidaklah pernah Aku menciptakan makhluk yang lebih Kuhargai dari engkau. Karena engkaulah Aku mengambil dan memberi dan karena engkaulah ${ }_{69}^{A k u}$ menurunkan pahala dan menjatuhkan hukuman.

Jelas dari hadits qudsi ini, bahwa akal merupakan ciptaan Tuhan yang tertinggi dan akal manusia yang dipakai Tuhan sebagai dasar dalam menentukan hukuman atau pahala yang akan diberikan pada seseorang.

Menurut keyakinan Islam, manusia adalah makhluk Tuhan. Keutamaan manusia dari makhluk lain terletak pada akal yang dianugerahkan akal kepadanya. Akal yang membuat manusia memiliki peradaban tinggi. Akal manusia yang mewujudkan ilmu pengetahuan dan teknologi. Dan selanjutnya ilmu pengetahuan dan teknologi yang dapat mengubah dan mengatur alam sekitar untuk kesejahteraan dan kebahagiaan manusia.

\section{b. Wahyu}

Wahyu dalam bentuk pertama kali kelihatannya adalah pengertian atau pengetahuan yang tiba-tiba dirasakan seseorang timbul dalam dirinya, timbul dengan tibatiba sebagai suatu cahaya yang menerangi jiwanya. Kedua, wahyu berupa pengalaman dan penglihatan dalam keadaan tidur atau dalam keadaan trance, ru'yat atau kasyf (vision). Ketiga, wahyu dalam bentuk yang diberikan melalui utusan atau malaikat, yaitu Jibril, dan wahyu serupa ini disampaikan dalam bentuk katakata.

Wahyu membawa ajaran-ajaran dasar yang selain jumlahnya tidak banyak, tetapi juga memberi ketentuan-ketentuan yang sifatnya masih global. Wahtu turun untuk memperkuat pendapat akal manusia tentang prinsip-prinsip kemasyarakatan yang benar. Di samping itu wahyu turun untuk menolong akal manusia dalam mengetahui hal-hal yang memang terletak di luar jangkauan akal, yaitu hal-hal yang berhubungan dengan hidup manusia di akhirat sesudah kehidupan di dunia. ${ }^{70}$ Kedua fungsi tersebut akan melengkapi apa saja yang bisa diketahui manusia lewat penggunaan akal.

Namun demikian, kalau akal telah dapat membedakan budi pekerti baik dan budi pekerti rendah, manusia dapat membuat norma-norma akhlak yang harus dipatuhi sesama manusia. Manusia tidak perlu

menunggu wahyu untuk mengatur hidup kemasyarakatannya. Wahyu turun kemudian untuk menyempumakan peraturan yang telah dibuat oleh akal manusia tersebut.

\section{c. Gebragan Harun}

Harun memang sangat tersosialisasi dalam tradisi intelektual dan akademis kosmopolitan (Barat). Tapi, sesungguhnya hampir sepenuhnya dia mewarisi dasardasar pemikiran Islam abad pertengahan. Penguasaannya yang mendalam terhadap pemikiranpemikiran para filsuf Islam, termasuk pengetahuannya yang luas terhadap dunia tasawuf, membuat ia dapat merumuskan konsep yang akurat tentang terapinya untuk membangun masyarakat Muslim Indonesia. Ia selalu mengatakan bahwa kebangkitan umat Islam tidak hanya ditandai dengan emosi keagamaan yang meluap-luap, tapi harus berdasarkan pemikiran yang dalam, menyeluruh, dan filosofis terhadap agama Islam itu sendiri. ${ }^{72}$

Informan adalah pihak-pihak yang dijadikan sumber data dalam sebuah penelitian. Sedangkan deskripsi informan diartikan sebagai gambaran tentang karakteristik informan. Deskripsi informan ini berkaitan dengan identitas informan (usia dan jenis kelamin), atau latar belakang kehidupan informan (latar belakang pendidikan dan latar belakang pekerjaan). Penggambaran deskripsi informan dalam penelitian ini bertujuan untuk memberikan gambaran dan tambahan pengetahuan mengenai keberagaman informan yang terdapat di Kecamatan Samigaluh. Pendeskripsian informan dalam penelitian ini tidak berkorelasi secara langsung terhadap hasil penelitian karena tabel dan grafik yang disajikan dalam penelitian ini ditampilkan secara umum atau mencakup keseluruhan karakteristik informan.

\section{DAFTAR PUSTAKA}

Harun Nasution, Pembelajaran Dalam Islam, (Jakarta: Bulan Bintang, 1975)

Harun Nasution, Teori Islam (Jakata: UI Press,1975) Harun Nasution, Filsafat Dan Mistisisme Dalam Islam (jakarta: Bulan Bintang, 19730

Mama Syaodih Sukmadinata, Pengembangan Kurikulum, (Bandung: Remaja Rosda Karya 2000)

Syaiful Muzani, Islam Rasional (Bandung, Mizan, 1995)

Abdurrahman masudi, Menuju Paradiqma Islam Humanis (Yogyakarta, Gama Media, 2003)

Anton Bakkea, Metode-Metode Filsafat (Jakarta: Ghalia Indonesia, 1984)

MasriSingarimbun, Metode Penelitian Survey (Jakarta: LP3ES, 1989)

ImamSuprayogo dan Taroni, Metode Penelitian Sosial Agama (Bandung: Remaja Rosda karya 2001)

Wila Hoky, Pengantar Sosiologi (Surabaya: Usaha Nasional,1986)

Deddy Mulyana, Metodelogi penelitian kualitatif (Bandung: Remaja Rosda Karya 20030 
S-Margono, Metodelogi Penelitian Pendidikan (Jakarta: Rineka Cipta 2003)

Suharsimi Arikunto, Prosedur penelitian Praktis (Jakarta: Bira Aksara, 1983)

Pemerintah RI, Undang-Undang No. 20 Tahun 2003 Tentang Sistem Pendidikan Nasional, (Bandung: Citra Unbara, 2003)

Hery Noer Aly dan Munszier Suparta, Pendidikan Islam Kini dan Mendatang.(Jakarta: CV.Triasco,2003)

Jusuf Amar Faisal, Reorintsi Pendidikan Isalm, (Jakarta: Gema Insani Press, 1995)

Mustaqim.(ed) Pemikiran Pendidikan Islam,(Semarang: Pustaka Pelaar, 1999)

Omar Muhammad Al-Toumy Al- Syaibany, Falsafah Pendidikan Islam, (terj). Hasan Langgulung, (Jakarta: Bulan Bintang, 1979)

Mastuhu, Menata Ulang Sistem Pendidikan dalam Abad 21, (Yogyakarta: MSI UII dan Safiria Insani Press, 2003)

Fasli Jalal, Reformasi Pendidikan dalam Konteks Otonomi Daerah, (Yogyakarta: Adicita, 2001)

Hasan Langgulung, Beberapa Pemikiran

Tentang

Pendidikan Islam, (Bandung: al Ma'arif, 1980)

Abuddin Nata, Ilmu Pendidikan Islam dengan Pendekatan Multidisipliner: Normatif Parenialis, Sejarah,

Filsafat, Psikologi, Sosiologi, Manajemen, Teknologi, Informasi, Kebudayaan, Politik, Hukum, (Jakarta: Rajawali Pers, 2010)

Husaini Usman dan Purnomo Setiady, Metode Penelitian Sosial, (Jakarta: Bumi Aksara, 2003)

Koentjoro Ningrat, Metode-Metode Penelitian Masyarakat, (Jakarta: PT. Gramedia, 1989)

Marzuki, Metodelogi Penelitian, (Yogyakarta: Andi Offset, 2002) 